\title{
The dual (activating/suppressive) effect of extracellular TatHIV-1 is driven by the infalmmatory microenvironment of infected lymphoid foci
}

\author{
Hélène Le Buanec ${ }^{1,2,3}$, Thomas Sené ${ }^{1,2,3}$, Armand Bensussan ${ }^{1,2,3}$, Robert Gallo ${ }^{4}$, Daniel Zagury ${ }^{*}$ \\ From 17th International Symposium on HIV and Emerging Infectious Diseases (ISHEID) \\ Marseille, France. 23-25 May 2012
}

It has been shown that HIV-1 infects activated but not resting CD4+ T cells [1] and that CPE induced by viral replication together with the immunosuppressive effect triggered by extracellular Tat protein [2] account for the decrease of $\mathrm{CD} 4+\mathrm{T}$ cell count in infected patients. In lymphoid foci, dependent on the level of viral infection, the stromal microenvironment surrounding immune cells could include, together with extracellular Tat [3] and circulating antiviral IFN- $\alpha$, inflammatory innate factors such as ATP and derivatives released by CPEderived dead cells.

We show that, according to its concentration and the presence of inflammatory factors (IFN- $\alpha$, ATP and ATP-derivatives), Tat protein may exert either an activation with enhanced production of IL2 or an immune suppression of stimulated CD4+ T cells subpopulations.

The double-edged sword of Tat activity on CD4+ T cells could account for its immunopathogenic effects both at the early stage of infection (by allowing CD4+ T cells activation and viral replication) and at late stages (by inducing immuosuppression, source of opportunistic infections). Indications for targeting Tat protein by therapeutic vaccines in subgroups of HIV-1 infected patients will be discussed.

\section{Author details}

${ }^{1}$ INSERM U976, F-75475, Paris, France. ${ }^{2}$ Université Paris Diderot, Sorbonne

Paris Cité, Laboratory of Immunology, Dermatology \& Oncology, UMR-S 976,

F-75475, Paris, France. ${ }^{3}$ Service de dermatologie, Hopital Saint Louis, F-75010,

* Correspondence: dzagury@neovacs.com

${ }^{5}$ Neovacs SA, Paris, France

Full list of author information is available at the end of the article
Paris, France. ${ }^{4}$ Institute of Human Virology, University of Maryland Baltimore, Maryland, USA. ${ }^{5}$ Neovacs SA, Paris, France.

Published: 25 May 2012

\section{References}

1. Zagury D, et al: Long-term cultures of HTLV-III-infected T cells: a model of cytopathology of T-cell depletion in AIDS. Science 1986, 231(4740):85

2. Viscidi RP, et al: Inhibition of antigen-induced lymphocyte proliferation by Tat protein from HIV- Science. 1989, 246(4937):1606.

3. Ensoli B, et al: Release, uptake, and effects of extracellular human immunodeficiency virus type 1 Tat protein on cell growth and viral transactivation. J Virol 1993, 67(1):277.

doi:10.1186/1742-4690-9-S1-P35

Cite this article as: Le Buanec et al: The dual (activating/suppressive) effect of extracellular TatHIV-1 is driven by the infalmmatory

microenvironment of infected lymphoid foci. Retrovirology 2012 9(Suppl 1):P35.

Submit your next manuscript to BioMed Central and take full advantage of:

- Convenient online submission

- Thorough peer review

- No space constraints or color figure charges

- Immediate publication on acceptance

- Inclusion in PubMed, CAS, Scopus and Google Scholar

- Research which is freely available for redistribution

Submit your manuscript at www.biomedcentral.com/submit 